\title{
MAIN SOCIAL ASPECTS OF AFFECTS THE FORMATION OF ADEQUATE KNOWLEDGE ABOUT REPRODUCTIVE HEALTH IN ADOLESCENCE GIRLS
}

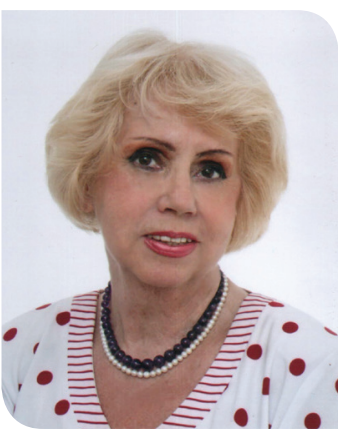

Z.A.SHKIRYAK-NYZHNYK

MD, professor, head of the Department of Medical and Psychosocial Problems of Family Health, Institute of Pediatrics, Obstetrics and Gynecology NAMS of Ukraine

ORCID: 0000-0002-4703-2427

N.K. SILINA

$\mathrm{PhD}$, senior researcher of the Department of Medical and Psychosocial Problems of Family Health, Institute of Pediatrics, Obstetrics and Gynecology NAMS of Ukraine

ORCID: 0000-0002-5456-8684

\section{O.V. LAPIKURA}

leading sociologist of the Department of Medical and Psychosocial Problems of Family Health, Institute of Pediatrics, Obstetrics and Gynecology NAMS of Ukraine

ORCID: 0000-0001-7629-2933

and others authors

Contacts:

Natalia K. Silina

Institute of Pediatrics, Obstetrics and Gynecology NAMS of Ukraine, Department of medical and psychosocial problems of the family 04050, Kyiv, Manuilskogo, 8 tel.: +38 (063) 3052131 e-mail: dr.silina@gmail.com

\section{INTRODUCTION}

The World Health Organization clearly indicates that reproductive health is a state of complete physical, mental and social well-being, and not the absence of reproductive disease or infertility. It is more important to remember that reproductive health is a reflection of health during childhood, and crucial during adolescence and adulthood, sets the stage for health beyond the reproductive years for women and affects the health of the next generation [1]. One of the statements that were made by the results of the International Conference on Population and Development, Cairo, 1994 is to implement the knowledge on reproductive health issues among adolescents and provide better access to education on this topic, and reveal the problem much broader than prevention of sexually transmitted diseases and unplanned pregnancy. Thus all developed countries spend money on implementation of educational programs among teens and regularly hold surveys on checking the average level of knowledge on this issue among teens and make regular analyses of the effectiveness of implemented programs.

\section{ANALYSIS OF PUBLISHED DATA AND THE} FORMULATION OF RESEARCH PROBLEMS

Parents, other family members and other information sources play an important role in cognition of interpersonal relationships and sexuality, especially for the younger age groups. There is a strong link between level of communication of teens and their parents and safe reproductive health habits [2].

Modern media, especially mobile phones and the Internet in a very short time have become important sources of information. But much of this information, particularly information on sexuality is distorted, contrived, untrue and often humiliating, especially for women (pornography on the Internet). Therefore, there is a new need for sex education caused by the need to prevent and correct misleading information and images transmitted by the media in the media. Thus it is necessary to include in the curricula of high school, college and university thematic cycles on healthy lifestyles, family planning, reproductive health, safe motherhood, prevention of oncogynecology pathology [3].

Many different types of programs have been shown to positively affect reproductive health outcomes. Not only school- and community-based sex education programs, but also clinic-based programs, youth development programs, service-learning programs, early childhood programs, and programs for young mothers have been found to improve reproductive health outcomes [4]. It was proved that communication and comfort between parents and adolescents about sexual issues decreases the initiation of sexual intercourse and these teens more likely to have conservative values [5]. But in order to realize educational program it is important to understand the level of knowledge of adolescents and main social factors that influence on formation of adequate reproductive health habits.

\section{MATERIALS AND METHODS}

We have analyzed data provided by the 532 girls at the "Questionnaire adolescents 15-18 years" from the database of Ukrainian longitudinal study "Family and Children of Ukraine" using parameters that characterize main social factors of influence on formation of life style habits.

\section{RESULTS OF THE STUDY AND DISCUSSION}

The significant percentage of interviewed girls for some reason does not demonstrate awareness of issues relating to sexual development and sexual relationships.

About 15\% of girls didn't give full answers about the characteristics of their menstrual cycle. Almost $16 \%$ gave incomplete answers on the issue of reproductive health problems $27 \%$ of girls did not answer at all on reproductive health issue. The questions of sexual development stages passed about $11 \%$ of girls. On the issue of sexual experience did not answer $35 \%$ of girls. There was no answer or incomplete answers given in $62 \%$ of cases on the question of optimal age of first sexual relations. But less than $5 \%$ of girls did not give informative answers on the issue of eroticism and pornography. It should be noted that almost $99 \%$ of girls from the survey reported on their sources of information on sexual relationships. Parents as the sources were indicated in $64 \%$ of cases, teachers and health workers in $44 \%$, and B in $25 \%$ of cases girls get information from unreliable sources - friends, the media and the Internet.

We have found that teens who are dissatisfied with the frequency of communication with their 
parents, received information on sexual relations from unreliable sources. Girls who talk often with parents on the reproductive health issue in $47.6 \%$ get this information from medical care providers.

Teens that determine deficit of communication with parents show less awareness in matters of sexual development. This group of girls is twice less informed in characteristics of normal menstrual cycle and parameters of reproductive health in comparison with the group of girls who are satisfied with their parent communication.

However, lack of communication with parents has no effect on the responses to the questions on sexual relationship.
Teens who do not communicate with their parents on the topic of sex and sexual relationships show less awareness in these issues: twice less in characteristics of normal menstrual cycle and reproductive health quality in comparison with those girls who regularly communicate with parents on this issue.

We could not confirm the hypothesis that the low-income family experience lack of communication between children and parents that has negative impact on the awareness of adolescent girls in terms of sex and sexual relationships (Table 1).

It was established that level of education of parents had no influence on the level of communication between parents and their children and on the level of awareness of adolescent girls in sex and sexual relationships issues (Table 2, 3).

\section{TABLE 1. CHARACTERISTICS OF GIRLS ANSWERS FROM LOW AND HIGH LEVEL OF FAMILY PROSPERITY AND CONNECTION BETWEEN THEIR COMMUNICATION WITH PARENTS AND THEIR ANSWERS ON THE REPRODUCTIVE HEALTH QUESTIONS}

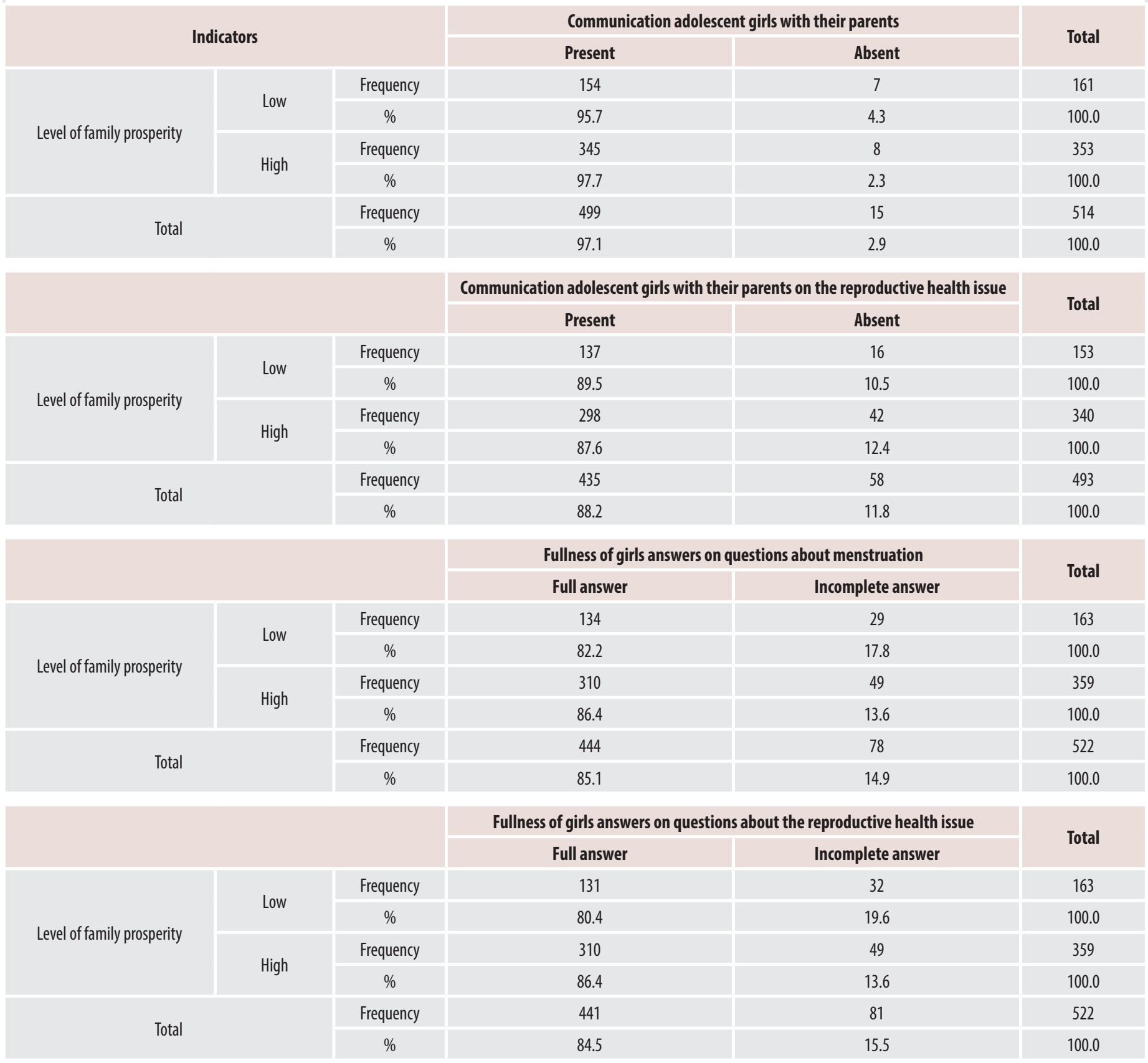


TABLE 1. CONTINUED

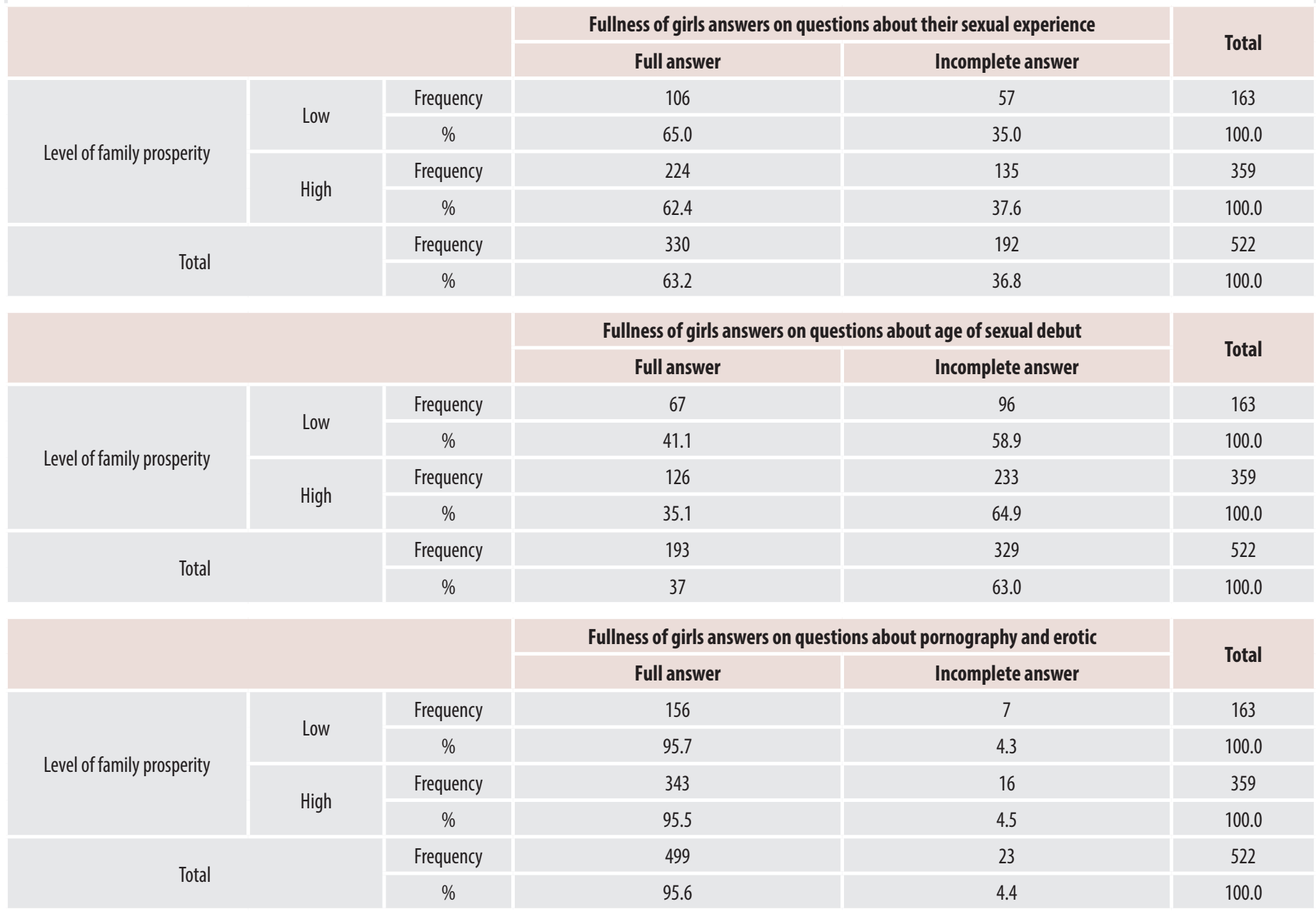

We have found that such social factors as poor level of living conditions, incomplete family in our surveyed group had no influence on the communication between parents and children. Also we didn't establish link between above mentioned social factors and level of knowledge on reproductive issues.

For our surveyed group the thesis that medical workers, psychologists and teachers as a reliable source of information about reproductive health and sexual relations has positive impact on the awareness of adolescent girls in issues of sex and sexual relationships wasn't proved. Percentage of awareness among girls receiving information from the experts is almost identical with the corresponding percentage for those who do not use the services of professionals.
We have revealed very low percentage of cases when specialists provide adolescent girl with the information on optimal age of sexual debut. $87 \%$ of interviewed girls got information on reproductive health from specialists, but only in almost $35 \%$ cases girls were informed about optimal age of sexual debut.

\section{CONCLUSION}

Among the surveyed adolescent girls fairly high amount does not demonstrate a high level of awareness in the issues of reproductive health, sexual development and sexual relationships. Evident link between the level of communication with adolescents and parents and level of

\section{TABLE 2. COMMUNICATION BETWEEN DAUGHTERS AND PARENTS DEPENDING ON MOTHER'S COMMUNICATION LEVEL}

\begin{tabular}{|c|c|c|c|c|c|}
\hline \multirow{2}{*}{\multicolumn{3}{|c|}{ Indicators }} & \multicolumn{2}{|c|}{ Communication adolescent girls with their parents } & \multirow{3}{*}{$\begin{array}{c}\text { Tota } \\
48\end{array}$} \\
\hline & & & Present & Absent & \\
\hline \multirow{4}{*}{ Level of mothers education } & \multirow{2}{*}{$\begin{array}{l}\text { Graduated from } \\
\text { high school }\end{array}$} & Frequency & 45 & 3 & \\
\hline & & $\%$ & 93.8 & 6.2 & 100.0 \\
\hline & \multirow{2}{*}{$\begin{array}{c}\text { Graduated from } \\
\text { university }\end{array}$} & Frequency & 394 & 54 & 448 \\
\hline & & $\%$ & 87.9 & 12.1 & 100.0 \\
\hline \multirow{2}{*}{\multicolumn{2}{|c|}{ Total }} & Frequency & 439 & 57 & 496 \\
\hline & & $\%$ & 88.5 & 11.5 & 100.0 \\
\hline
\end{tabular}


TABLE 3. CHARACTERISTICS OF REPRODUCTIVE HEALTH QUESTIONS OF THE TEENS DEPENDING ON THE MOTHER'S EDUCATION LEVEL

\begin{tabular}{|c|c|c|c|c|c|}
\hline \multirow{2}{*}{\multicolumn{3}{|c|}{ Indicators }} & \multicolumn{2}{|c|}{ Fullness of girls answers on questions about menstruation } & \multirow{3}{*}{$\begin{array}{c}\text { Total } \\
50\end{array}$} \\
\hline & & & Full answer & Incomplete answer & \\
\hline \multirow{3}{*}{ Level of mothers education } & $\begin{array}{l}\text { Graduated from } \\
\text { high school }\end{array}$ & Frequency & 40 & 10 & \\
\hline & \multirow{2}{*}{$\begin{array}{l}\text { Graduated from } \\
\text { university }\end{array}$} & Frequency & 408 & 67 & 475 \\
\hline & & $\%$ & 85.9 & 14.1 & 100.0 \\
\hline \multicolumn{2}{|l|}{ Total } & $\%$ & 85.3 & 14.7 & 100.0 \\
\hline & & & \multicolumn{2}{|c|}{ Fullness of girls answers on questions about the reproductive health issue } & \multirow{2}{*}{ Total } \\
\hline & & & Full answer & Incomplete answer & \\
\hline Level of mothers education & $\begin{array}{l}\text { Graduated from } \\
\text { high school }\end{array}$ & Frequency & 39 & 11 & 50 \\
\hline \multirow{2}{*}{\multicolumn{2}{|c|}{ Total }} & Frequency & 446 & 79 & 525 \\
\hline & & $\%$ & 85 & 15.0 & 100.0 \\
\hline & & & \multicolumn{2}{|c|}{ Fullness of girls answers on questions about their sexual experience } & \multirow{2}{*}{ Total } \\
\hline & & & Full answer & Incomplete answer & \\
\hline \multirow{4}{*}{ Level of mothers education } & \multirow{2}{*}{$\begin{array}{l}\text { Graduated from } \\
\text { high school }\end{array}$} & Frequency & 26 & 24 & 50 \\
\hline & & $\%$ & 52.0 & 48.0 & 100.0 \\
\hline & \multirow{2}{*}{$\begin{array}{l}\text { Graduated from } \\
\text { university }\end{array}$} & Frequency & 307 & 168 & 475 \\
\hline & & $\%$ & 64.6 & 35.4 & 100.0 \\
\hline \multirow{3}{*}{ Level of mothers education } & $\begin{array}{l}\text { Graduated from } \\
\text { high school }\end{array}$ & $\%$ & 40.0 & 60.0 & 100.0 \\
\hline & \multirow{2}{*}{$\begin{array}{l}\text { Graduated from } \\
\text { university }\end{array}$} & Frequency & 176 & 299 & 475 \\
\hline & & $\%$ & 37.1 & 62.9 & 100.0 \\
\hline \multirow{2}{*}{\multicolumn{2}{|c|}{ Total }} & Frequency & 196 & 329 & 525 \\
\hline & & $\%$ & 37.3 & 62.7 & 100.0 \\
\hline & & & Fullness of girls an & oornography and erotic & \multirow{2}{*}{ Total } \\
\hline & & & Full answer & Incomplete answer & \\
\hline & Graduated from & Frequency & 48 & 2 & 50 \\
\hline lovel of mothers education & high school & $\%$ & 96.0 & 4.0 & 100.0 \\
\hline Level of mothers education & Graduated from & Frequency & 453 & 22 & 475 \\
\hline & university & $\%$ & 95.4 & 4.6 & 100.0 \\
\hline Tntal & & Frequency & 501 & 24 & 525 \\
\hline IOtal & & $\%$ & 95.4 & 4.6 & 100.0 \\
\hline
\end{tabular}

knowledge on reproductive health issues at this group of girls was found - the girls that point on the family communication deficits had given less informative answer on questions concerning the development of the reproductive and sexual relations, and more often choose as information source on

this topic unreliable and badly controlled sources - friends, the media and the Internet. However, among adolescents who are satisfied with the level of communication with their parents (vast majority -97\%), the percentage of badly informed is also noticeable. 
Attempts to identify the specific target group for family's educational programs were unsuccessful. Parameters that are considered as risk factors for social anamnesis - property status, education level of parents, staff and family housing don't have a real impact on the deficit in family communication and adolescent's awareness. Probably, it is more preferable is to implement general educational programs for teens instead of programs for targeted audience.
However, it is worth noting that $56 \%$ of girls didn't receive information about reproductive and sexual development from specialists - health workers, psychologists and teachers, but their level of knowledge doesn't significantly differs from those who got such information from experts.

We can conclude that existing educational programs are not sufficiently effective, and the means provided for existing programs do not provide adequate coverage of adolescents.

\section{ЛИТЕРATУPA/REFERENCES}

1. World Health Organization news release.

"WHO calls for stronger focus on adolescent health." [http:// www.who.int/mediacentre/news/releases/2014/focusadolescent-health/en/], last accessed Dec 22, 2015.

2. Dessie, Y., Berhane, Y., Worku, A.

"Parent-Adolescent Sexual and Reproductive Health

Communication Is Very Limited and Associated with Adolescent

Poor Behavioral Beliefs and Subjective Norms: Evidence from a Community Based Cross-Sectional Study in Eastern Ethiopia."

PLoS One, 10(7) (2015): e0129941.

D0I: 10.1371/journal.pone.0129941

3. Петрунько, 0 .

Статева просвіта в умовах загальноосвітньоїшколи / 0 .

Петрунько // Соц. психологія. — 2006. — № 5.

Petrunko, 0 .

"Sexual education in general schools." Social psychology, $5(2006)$.
4. Ball, V.N, Moore, K.A.

"What works for adolescent reproductive health: Lessons from Experimental Evaluations of Programs and Interventions." [http://www.childtrends.org/wp-content/uploads/2013/03/ Child Trends-2008 05 20 FS WhatWorksRepro.pdf], last accessed Dec 22, 2015.

5. Dilorio, C., Kelley, M., Hockenberry-Eaton, M.

"Communication about sexual issues: mothers, fathers, and friends."J Adolesc Health, 24(3) (1999):181-189.

\section{MAIN SOCIAL ASPECTS OF AFFECTS THE FORMATION OF ADEQUATE KNOWLEDGE ABOUT REPRODUCTIVE HEALTH IN ADOLESCENCE GIRLS}

Z.A. Shkiryak-Nyzhnyk, MD, professor, head of the Department of Medical and Psychosocial Problems of Family Health, Institute of Pediatrics, Obstetrics and Gynecology NAMS of Ukraine

N.K. Silina, PhD, senior researcher of the Department of Medical and Psychosocial Problems of Family Health, Institute of Pediatrics, Obstetrics and Gynecology NAMS of Ukraine

0.V. Lapikura, leading sociologist of the Department of Medical and Psychosocial Problems of Family Health, Institute of Pediatrics, Obstetrics and Gynecology NAMS of Ukraine

L.N. Slobodchenko, scientific researcher of the Department of Medical and Psychosocial Problems of Family Health, Institute of Pediatrics, Obstetrics and Gynecology NAMS of Ukraine

0.V. Zvinchuk, scientific researcher of the Department of Medical and Psychosocial Problems of Family Health, Institute of Pediatrics, Obstetrics and Gynecology NAMS of Ukraine

E.I. Nepochatova-Kurashkevich, PhD, senior researcher of the Department of Medical and Psychosocial Problems of Family Health, Institute of Pediatrics, Obstetrics and Gynecology NAMS of Ukraine

L.M. Sinchuk, PhD, senior researcher of the Department of Medical and Psychosocial Problems of Family Health, Institute of Pediatrics, Obstetrics and Gynecology NAMS of Ukraine

A.I. Matcola, leading psyhologist of the Department of Medical and Psychosocial Problems of Family Health, Institute of Pediatrics, Obstetrics and Gynecology NAMS of Ukraine

Reproductive health is a reflection of health during childhood, and crucial during adolescence and adulthood, sets the stage for health beyond the reproductive years for women and affects the health of the next generation. Many different types of educational programs, based on local peculiarities have been shown to positively affect reproductive health outcomes. Thus we decided to analyze the "Questionnaire adolescents $15-18$ years" of 532 girls from the database of Ukrainian longitudinal study "Family and Children of Ukraine" using parameters that characterize main social factors of influence on formation of life style habits at adolescent girls.

Among the surveyed adolescent girls fairly high amount does not demonstrate a high level of awareness in the issues of reproductive health, sexual development and sexual relationships. Evident link between the level of communication with adolescents and parents and level of knowledge on reproductive health issues at this group of girls was found - the girls that point on the family communication deficits had given less informative answer on questions concerning the development of the reproductive and sexual relations, and more often choose as information source on this topic unreliable and badly controlled sources - friends, the media and the Internet. However, among adolescents who are satisfied with the level of communication with their parents (vast majority - 97\%), the percentage of badly informed is also noticeable.

Parameters that are considered as risk factors for social anamnesis - property status, education level of parents, family housing - don't have a real impact on the deficit in family communication and adolescent's awareness.

However, it is worth noting that $56 \%$ of girls didn't receive information about reproductive and sexual development from specialists - health workers, psychologists and teachers, but their level of knowledge doesn't significantly

differs from those who got such information from experts.

We can conclude that existing educational programs are not sufficiently effective, and the means provided for existing programs do not provide adequate coverage of adolescents.

Keywords: reproductive health, adolescent girls, educational programs.

\section{ОСНОВНІ СОЦІАЛЬНІ АСПЕКТИ, ЩО ВПЛИВАЮТЬ НА ФОРМУВАННЯ НЕОБХІДНИХ ЗНАНЬ ПРО РЕПРОДУКТИВНЕ ЗДОРОВ'Я У ДІВЧАТ-ПІДЛІТКІВ}

3.А. Шкіряк-Нижник, д. мед. н., професор, зав. відділенням медичних та психосоціальних проблем здоров'я сім'ї ІПАГ НАМН України

Н.К. Сіліна, к. мед. Н., Ст. наук. співробітник відділення медичних та психосоціальних проблем здоров'я сім'ї ІПАГ НАМН України

0.В. Лапікура, провідний соціолог відділення медичних та психосоціальних проблем здоров'я сім'ї ІПАГ НАМН України

Л.М. Слободченко, наук. співробітник відділення медичних та психосоціальних проблем здоров'я сім'ї ІПАГ НАМН України

О.В. Звінчук, наук. співробітник відділення медичних та психосоціальних проблем здоров'я сім'ї ІПАГ НАМН України

Е.І. Непочатова-Курашкевич, к. мед. Н., ст. наук. співробітник відділення медичних та психосоціальних проблем здоров'я сім'ї ІПАГ НАмН України

Л.М. Сінчук, к. мед. н., ст. наук. співробітник відділення медичних та психосоціальних проблем здоров'я сім'ї ІПАГ НАМН України

А.М. Мацола, провідний психолог відділення медичних та психосоціальних проблем здоров'я сім'ї ІПАГ НАМН України

Репродуктивне здоров'я сучасної жінки - це відображення стану її здоров'я в дитинстві і в підлітковому віці, що, крім іншого, впливає на здоров'я майбутніх поколінь. Існує багато різних освітніх програм, розроблених на основі регіональних особливостей, які показали позитивні результати в репродуктивних наслідках. Ми проаналізували «0питувальник підлітків $15-18$ років», який заповнили 532 дівчини з бази даних українського поздовжнього дослідження «Сім'я д діти України», використовуючи параметри, що характеризують основні соціальні фактори впливу на формування звичок і способу життя в дівчаток-підлітків.

Досить велика кількість обстежених дівчаток-підлітків не продемонстрували високий рівень поінформованості в питаннях репродуктивного здоров'я, статевого розвитку і сексуальних відносин. Нами виявлений очевидний зв'язок між рівнем комунікації підлітків з батьками та рівнем знань щодо питань репродуктивного здоров'я. Так, дівчата, які вказують на дефіцит сімейного зв'язку, дали менш інформативну відповідь на питання, що стосуються розвитку репродуктивної системи і сексуальних відносин. При цьому вони частіше вибирають як джерела інформації з цієї теми ненадійні і погано контрольовані джерела - друзів, засоби масової інформації та інтернет. Із усім тим, серед підлітків, які задоволені рівнем спілкування зі своїми батьками (переважна більшість - 97\%), відсоток погано інформованих є також високим.

Параметри, які вважаються факторами ризику для соціального анамнезу - фінансове становище, рівень освіти батьків, сімейне житло - не справляли істотного впливу на дефіцит сімейного спілкування та поінформованість підлітка.

Окрім того, варто відзначити, щ0 56\% дівчат зовсім не отримують інформацію про репродуктивний і сексуальний розвиток від фахівців - медичних працівників, психологів і педагогів, але їхній рівень знань незначно відрізняється від дівчат, які отримали таку інформацію від експертів.

Ми можемо зробити висновок, що існуючі освітні програми не є достатньо ефективними, і засоби, передбачені для існуючих програм, не забезпечують адекватного охоплення дівчаток підліткового віку. Ключові слова: репродуктивне здоров'я, дівчата-підлітки, освітні програми.

\section{ОСНОВНЫЕ СОЦИАЛЬНЫЕ АСПЕКТЫ, ВЛИЯЮЩИЕ НА ФОРМИРОВАНИЕ НЕОБХОДИМЫХ ЗНАНИЙ О РЕПРОДУКТИВНОМ ЗДОРОВЬЕ У ДЕВОЧЕК-ПОДРОСТКОВ}

3.А. Шкиряк-Нижник, д. мед. н., профессор, зав. отделением медицинских и психосоциальных проблем здоровья семьи ИПАГ НАМН Украины

Н.К. Силина, к. мед. Н., ст. науч. сотрудник отделения медицинских и психосоциальных проблем здоровья семьи ИПАГ НАМН Украины

0.В. Лапикура, ведущий социолог отделения медицинских и психосоциальных проблем здоровья семьи ИПАГ НАМН Украины

Л.Н. Слободченко, науч. сотрудник отделения медицинских и психосоциальных проблем здоровья семьи ИПАГ НАМН Украинь

А.В. Звинчук, науч. сотрудник отделения медицинских и психосоциальных проблем здоровья семьи ИПАГ НАМН Украины

Э.И. Непочатова-Курашкевич, к. мед. Н., ст. науч. сотрудник отделения медицинских и психосоциальных проблем здоровья семьи ИПАГ НАМН Украинь

Л.М. Синчук, к. мед. Н., ст. науч. сотрудник отделения медицинских и психосоциальных проблем здоровья семьи ИПАГ НАМН Украины

А.Н. Мацола, ведущий психолог отделения медицинских и психосоциальных проблем здоровья семьи ИПАГ НАМН Украины

Репродуктивное здоровье современной женщины - это отражение состояния ее здоровья в детстве и в подростковом возрасте, что, помимо прочего, влияет на здоровье будущих поколений. Существует много различных образовательных программ, разработанных на основе региональных особенностей, которые показали положительные результаты в репродуктивных исходах. Мы проанализировали «Вопросник подростков 15-18 лет», который заполнили 532 девушки из базы данных украинского продольного исследования «Семья и дети Украины», используя параметры, характеризующие основные социальные факторы влияния на формирование привычек и образа жизни у девочек-подростков.

Довольно большое количество обследованных девочек-подростков не продемонстрировали высокий уровень осведомленности в вопросах репродуктивного здоровья, полового развития и сексуальных отношений. Нами выявлена очевидная связь между уровнем коммуникации подростков с родителями и уровнем знаний по вопросам репродуктивного здоровья. Так, девушки, которые указывают на дефицит семейной связи, дали менее информативный ответ на вопросы, касающиеся развития репродуктивной системы и сексуальных отношений. При этом они чаще выбирают в качестве источника информации по этой теме ненадежные и плохо контролируемые источники - друзей, средства массовой информации и интернет. Тем не менее, среди подростков, которые удовлетворены уровнем общения со своими родителями (подавляющее большинство - 97\%), процент плохо информированных является также высоким.

Параметры, которые считаются факторами риска для социального анамнеза - финансовое положение, уровень образования родителей, семейное жилье - не оказывали существенного влияния на дефицит семейного общения и осведомленность подростка.

Кроме того, стоит отметить, что 56\% девушек вовсе не получают информацию о репродуктивном и сексуальном развитии от специалистов - медицинских работников, психологов и педагогов, но их уровень знаний незначительно отличается от девушек, получивших такую информацию от экспертов.

Мы можем сделать вывод, что существующие образовательные программы не являются достаточно эффективными, и средства, предусмотренные для существующих программ, не обеспечивают адекватного охвата девочек подросткового возраста.

Ключевые слова: репродуктивное здоровье, девочки-подростки, образовательные программы. 